\title{
ATMOSPHERIC TRANSMISSIVITY: DISTRIBUTION AND EMPIRICAL ESTIMATION AROUND THE CENTRAL ANDES
}

\author{
GUILLERMO A. BAIGORRIA, ${ }^{\mathrm{a}, \mathrm{b}, *}$ ESEQUIEL B. VILLEGAS, ${ }^{\mathrm{c}}$ IRENE TREBEJO, $^{\mathrm{c}} \mathrm{JOSE}^{\mathrm{F} .} \mathrm{CARLOS}^{\mathrm{c}}$ and \\ ROBERTO QUIROZ \\ a Department of Production Systems and Natural Resources Management, International Potato Center, PO Box 1558, Lima 12, Peru \\ ${ }^{\mathrm{b}}$ Laboratory of Soil Science and Geology, Wageningen University, PO Box 37, 6700 AA Wageningen, The Netherlands \\ c Dirección General de Investigación y Asuntos Ambientales, Servicio Nacional de Meteorología e Hidrología de Perú, PO Box 1308, \\ Lima 11, Peru \\ Received 5 November 2003 \\ Revised 19 April 2004 \\ Accepted 20 April 2004
}

\begin{abstract}
This study of the distribution in space and time of atmospheric transmissivity $\tau$ takes into account the fact that, in complex terrain, many factors affect this variable; thus, it is not possible to use the generalizations that can be applied under more homogeneous conditions. Climatic controls, topography and even sea currents have important effects on clouds and aerosols affecting $\tau$, simultaneously leading to differences in the distribution of incident solar radiation. Different models exist to estimate incoming solar radiation as a function of relative sunshine hours (observed sunshine hours/theoretical sunshine hours, $n / N)$ or differences between maximum and minimum temperatures $\Delta T$. We calibrated, validated and evaluated four of these empirical relations based on data from 15 weather stations in Peru. Models were calibrated using $66 \%$ of the daily historical record available for each weather station; the rest of the information was used for validation and comparison. The Ångström-Prescott model was used to estimate incoming solar radiation based on $n / N$, and gave the best performance of all the models tested. The other models (Bristow-Campbell, Hargreaves, and Garcia) estimated incoming solar radiation based on $\Delta T$. Of all the models in this group, the Bristow-Campbell model performed best; it is also valuable because of the physical explanation involved. The empirical coefficients of all the models evaluated are presented here. Two empirical equations are proposed with which to estimate values of the coefficients $b_{\mathrm{B}}$ and $c_{\mathrm{B}}$ in the Bristow-Campbell model, as a function of $\Delta T$ and latitude, allowing the model to be applied to other study areas. Copyright (c) 2004 Royal Meteorological Society.
\end{abstract}

KEY WORDS: atmospheric transmissivity; incoming solar radiation; Ångström-Prescott; sunshine hours; Bristow-Campbell; temperature; complex terrain

\section{INTRODUCTION}

Atmospheric transmissivity $\tau$ in Peru is mainly affected by climatic controls, such as the semi-permanent high-pressure cells over the Pacific and Atlantic Oceans, the Bolivian high (a high-pressure cell in the upper levels of the troposphere), the near-equatorial trough, the cool Humboldt or Peruvian Current, and the Andes mountain range. Over space and time, the interactions of all these climatic controls over complex terrains cause different moisture features in the atmosphere affecting $\tau$. In conjunction with the apparent movement of the sun from one hemisphere to the other, a complex pattern of incident solar radiation develops that does not just correspond to the effects of altitude and latitude.

Incoming solar radiation $H$ is one of the most important variables in meteorology, since it is the energy source underlying the majority of processes on our planet. Both the total amount of incoming solar radiation and the distribution of that radiation are becoming increasingly important variables in agricultural sciences,

* Correspondence to: Guillermo A. Baigorria, Department of Production Systems and Natural Resources Management, International Potato Center, PO Box 1558, Lima 12, Peru; e-mail: g.baigorria@cgiar.org 
due to the introduction of process-based models used to simulate crop growth (Tsuji et al., 1998). The development of photovoltaic panels has provided another reason for understanding the variation that occurs in incoming solar radiation over space and time, since its availability and distribution determine the size of the photovoltaic panels needed for a given application or location. However, despite their importance, measurements of incoming solar radiation are infrequent, since the equipment is costly and highly specialized. In developing countries like Peru, stations where incoming solar radiation can be measured are few and far between. The high spatial variability that occurs both in topography and climate means that irradiation measurements are representative of only very small areas.

Several methods to estimate incoming solar radiation using radiative transfer models and satellites have been developed around the world (Atwater and Ball, 1978; Weymouth and Le Marshall, 1994; Bastos et al., 1996; Ceballos and Moura, 1997; Dissing and Wendler, 1998; Garatuza-Payan et al., 2001; Gultepe et al., 2001). However, they have all been developed away from mountainous areas because of the lack of data for calibration and validation, and because of the complexities in topography, thus needing more complex algorithms to explain the radiative fluxes.

Therefore, it is necessary to generate and calibrate empirical relationships that estimate incoming solar radiation as a function of other known meteorological variables, e.g. as performed by Ångström (1924), Prescott (1940), Frère et al. (1975), Cengiz et al. (1981), Hargreaves and Samani (1982), Bristow and Campbell (1984), Garcia (1994), Goodin et al. (1999), and Mahmood and Hubbard (2002). Relative sunshine hours, cloudiness and temperature are frequently measured by weather stations. The use of these variables to estimate incoming solar radiation can help in understanding its variation in time and space.

\section{DATA}

Peru is located between latitudes $0^{\circ} 01^{\prime} 48^{\prime \prime} \mathrm{S}$ and $18^{\circ} 21^{\prime} 03^{\prime \prime} \mathrm{S}$, and between longitudes $68^{\circ} 39^{\prime} 27^{\prime \prime} \mathrm{W}$ and $81^{\circ} 20^{\prime} 11^{\prime \prime} \mathrm{W}$. Ranging in altitude from 0 to $6768 \mathrm{~m}$ above sea level (a.s.l.), the country has a surface area of $1285215 \mathrm{~km}^{2}$. Fourteen weather stations from the Peruvian national meteorology and hydrology service (SENAMHI), all containing instruments for measuring incoming solar radiation, sunshine hours and maximum and minimum temperatures, were used in the present work. These weather stations (Table I) are located throughout Peru, and cover the variation that occurs between the coastal, highland and jungle areas;

Table I. Geographical location, historical records and instruments used to measure incoming solar radiation in Peru

\begin{tabular}{lccccc}
\hline ID Location & Latitude $\left({ }^{\circ} \mathrm{S}\right)$ & Longitude $\left({ }^{\circ} \mathrm{W}\right)$ & Altitude $(\mathrm{m})$ & $\begin{array}{c}\text { Historical } \\
\text { records }\end{array}$ & Instrument \\
\hline 1 Miraflores & $5^{\circ} 10^{\prime}$ & $80^{\circ} 37^{\prime}$ & 30 & $1979-92$ & Pyranometer \\
2 San Ramon SM & $5^{\circ} 56^{\prime}$ & $76^{\circ} 05^{\prime}$ & 184 & $1972-82$ & Actinograph \\
3 El Porvenir & $6^{\circ} 35^{\prime}$ & $76^{\circ} 19^{\prime}$ & 230 & $1964-71$ & Actinograph \\
4 Bambamarca & $6^{\circ} 40^{\prime}$ & $78^{\circ} 31^{\prime}$ & 2536 & $1967-77$ & Actinograph \\
5 Bellavista & $7^{\circ} 03^{\prime}$ & $76^{\circ} 33^{\prime}$ & 247 & $1971-73$ & Actinograph \\
6 Weberbauer & $7^{\circ} 10^{\prime}$ & $78^{\circ} 30^{\prime}$ & 2536 & $1980-85$ & Pyranometer \\
7 Huayao & $12^{\circ} 02^{\prime}$ & $75^{\circ} 19^{\prime}$ & 3308 & $1977-96$ & Pyranometer \\
8 A. von Humboldt & $12^{\circ} 05^{\prime}$ & $76^{\circ} 56^{\prime}$ & 238 & $1968-99$ & Pyranometer \\
9 Cosmos & $12^{\circ} 09^{\prime}$ & $75^{\circ} 34^{\prime}$ & 4575 & $1986-88$ & Pyranometer \\
10 Granja Kcayra & $13^{\circ} 33^{\prime}$ & $71^{\circ} 52^{\prime}$ & 3219 & $1980-88$ & Pyranometer \\
11 San Camilo & $14^{\circ} 04^{\prime}$ & $75^{\circ} 43^{\prime}$ & 398 & $1978-88$ & Pyranometer \\
12 Chuquibambilla & $14^{\circ} 47^{\prime}$ & $70^{\circ} 44^{\prime}$ & 3971 & $1980-84$ & Pyranometer \\
13 Puno & $15^{\circ} 49^{\prime}$ & $70^{\circ} 00^{\prime}$ & 3820 & $1977-93$ & Pyranometer \\
14 Characato & $16^{\circ} 27^{\prime}$ & $71^{\circ} 29^{\prime}$ & 2451 & $1978-87$ & Pyranometer \\
15 La Joya & $16^{\circ} 35^{\prime}$ & $71^{\circ} 55^{\prime}$ & 1295 & $1967-93$ & Actinograph \\
\hline
\end{tabular}




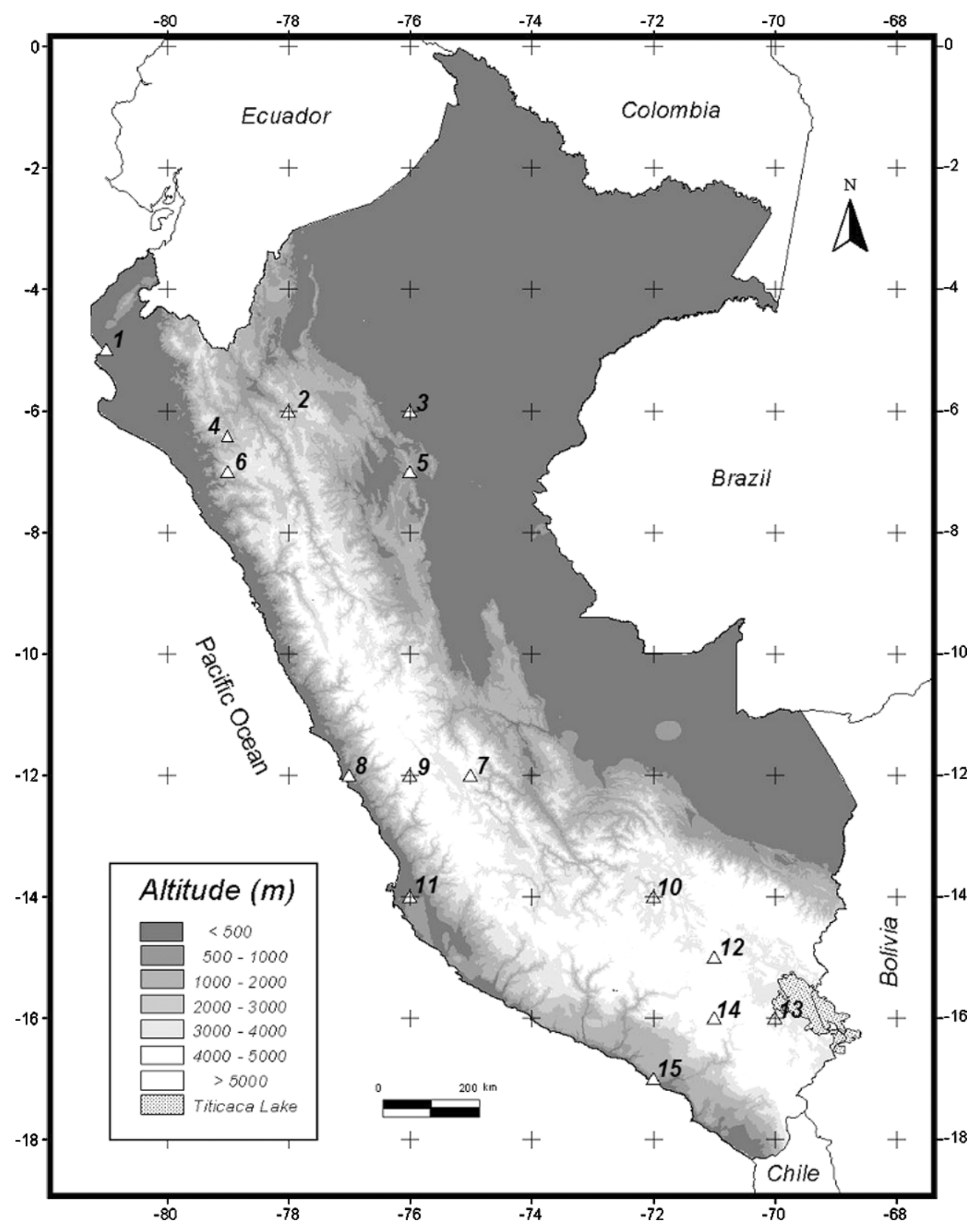

Figure 1. Digital elevation model of Peru and location of the weather stations used. For identification numbers, see Table I

they cover the length of the country (north to south; Figure 1). The climatic variations in these locations are presented in Table II.

Data on incoming solar radiation were obtained from pyranometers and actinographs; sunshine hours were read from Campbell-Stokes heliographs. All the information used was recorded at hourly intervals, and was taken from the complete historical record of each weather station.

After the aggregation of the hourly data from all the meteorological stations into daily intervals, consistency analyses were performed. These analyses included: the identification of transcription errors caused when transferring data from manual files; the detection of systematic errors caused by instruments and present in 
Table II. Main climatic characteristics of the locations

\begin{tabular}{|c|c|c|c|c|c|}
\hline \multirow[t]{2}{*}{ Location } & \multirow{2}{*}{$\begin{array}{l}\text { Incoming solar radiation } \\
\qquad\left(\mathrm{MJ} \mathrm{m}^{-2} \mathrm{day}^{-1}\right)\end{array}$} & \multirow{2}{*}{$\begin{array}{l}\text { Relative sunshine } \\
\text { duration }(\%)\end{array}$} & \multicolumn{2}{|c|}{ Temperature $\left(^{\circ}\right)$} & \multirow{2}{*}{$\begin{array}{l}\text { Total annual } \\
\text { rainfall }(\mathrm{mm})\end{array}$} \\
\hline & & & Maximum & Minimum & \\
\hline \multicolumn{6}{|l|}{ Coast } \\
\hline Miraflores & 20.7 & 56 & 30.7 & 19.3 & 216 \\
\hline A. von Humboldt & 14.6 & 40 & 23.3 & 15.5 & 16 \\
\hline San Camilo & 21.3 & 61 & 28.7 & 13.4 & 11 \\
\hline La Joya & 25.3 & 75 & 27.0 & 10.1 & 77 \\
\hline \multicolumn{6}{|l|}{ Highlands } \\
\hline Bambamarca & 16.4 & 44 & 19.4 & 9.5 & 737 \\
\hline Weberbauer & 17.7 & 49 & 21.3 & 7.6 & 644 \\
\hline Cosmos & 17.7 & 46 & 9.2 & -0.7 & 1047 \\
\hline Huayao & 21.6 & 56 & 19.6 & 4.4 & 765 \\
\hline Granja Kcayra & 19.6 & 53 & 20.7 & 3.7 & 674 \\
\hline Chuquibambilla & 21.9 & 59 & 16.8 & -2.4 & 715 \\
\hline Puno & 22.9 & 70 & 14.7 & 2.6 & 753 \\
\hline Characato & 23.4 & 73 & 22.8 & 6.8 & 78 \\
\hline \multicolumn{6}{|l|}{ Jungle } \\
\hline San Ramon SM & 16.8 & 41 & 31.3 & 20.8 & 2158 \\
\hline El Porvenir & 14.0 & 41 & 32.5 & 20.4 & 1041 \\
\hline Bellavista & 17.2 & 40 & 32.2 & 20.9 & 928 \\
\hline
\end{tabular}

bands; the identification of errors related to the reading of bands; and the identification of errors associated with measurement units and the use of conversion factors. In addition, comparisons were made of extraterrestrial incoming solar radiation $H_{\mathrm{o}}$ (Peixoto and Oort, 1992) and potential or theoretical sunshine hours $N$ according to latitude. The behaviour of the parameters over time was also included, in order to identify jumps within the historical record. Questionable data were analysed individually, including checks of the synoptic characteristics for a specific day. Outliers in the data for which there was no apparent explanation were disposed of in order to avoid errors in the analysis.

\section{METHODS}

\subsection{Spatial distribution of the atmospheric transmissivity coefficient $\tau$}

Transmissivity $\tau(\%)$ was calculated for all the weather stations considered in this paper using

$$
\tau=\frac{H}{H_{\mathrm{o}}} \times 100
$$

where $H\left(\mathrm{MJ} \mathrm{m}^{-2} \mathrm{day}^{-1}\right)$ is the measured incoming solar radiation, $H_{\mathrm{o}}\left(\mathrm{MJ} \mathrm{m}^{-2} \mathrm{day}^{-1}\right)$ is the extraterrestrial incoming solar radiation (calculated as a function of the ratio between actual and mean sun-Earth distance, latitude, solar declination and solar angle at sunrise). These values were plotted onto a map of the topography of the area. To allow spatial analysis of this variable, lines joining points with equal values of $\tau$ were plotted.

\subsection{Model based on sunshine hours: Ångström-Prescott model}

The Ångström-Prescott model is the most frequently used model to estimate the relative incoming solar radiation $H / H_{\mathrm{o}}$ equivalent to the atmospheric transmissivity coefficient $\tau$. It is based on relative sunshine 
hours $n / N$. This equation suggested by Prescott (1940), is a modification of that proposed by Ångström (1924):

$$
\frac{H}{H_{\mathrm{o}}}=a+b \frac{n}{N}
$$

where $n$ is the number of effective sunshine hours measured with a heliograph and $N$ is the potential or theoretical number of sunshine hours. The coefficients $a$ and $b$ are empirical; however, they have some physical explanation. The $a+b$ value represents the maximum atmospheric transmission coefficient $\tau$, and $a$ represents the minimum value of $\tau$.

Frère et al. (1975) proposed values of $a=0.29$ and $b=0.42$ as being applicable not only to Peru, but also to all the Andean highlands. These values were based on both the high rates of incoming solar radiation that occur as a result of the altitude of these zones and an annual mean of relative sunshine hours (taken to be around $50 \%$ as a general value). This idea was rejected for Peru by Garcia (1994), who proposed the application of empirical coefficients at regional scales because of the different climatic conditions that prevail.

\subsection{Model based on temperatures}

According to Bristow and Campbell (1984), the size of the difference between daily maximum and minimum air temperatures depends on the Bowen ratio (i.e. the relationship between sensible heat and latent heat). Sensible heat depends on daily incoming solar radiation and is responsible for maximum air temperatures. At night, sensible heat is lost into space as longwave radiation; together with radiative fluxes, this results in a decrease in air temperature until the daily minimum temperature is reached, usually just before sunrise. This physical explanation justifies the use of these kinds of model, with the advantage given by the use of a widespread network of weather stations that allow measurements to be made of daily extremes of temperature.

3.3.1. Bristow-Campbell model. Bristow and Campbell (1984) proposed a model with which to estimate relative incoming solar radiation as a function of the difference between maximum and minimum temperatures $\Delta T\left({ }^{\circ} \mathrm{C}\right)$ :

$$
\frac{H}{H_{\mathrm{o}}}=a_{\mathrm{B}}\left[1-\exp \left(-b_{\mathrm{B}} \Delta T^{c_{\mathrm{B}}}\right)\right]
$$

The empirical coefficients $\left(a_{\mathrm{B}}, b_{\mathrm{B}}\right.$ and $\left.c_{\mathrm{B}}\right)$ have some physical explanation. The coefficient $a_{\mathrm{B}}$ represents the maximum value of $\tau$, is characteristic of a study area, and depends on pollution and elevation. The coefficients $b_{\mathrm{B}}\left({ }^{\circ} \mathrm{C}^{-1}\right)$ and $c_{\mathrm{B}}$ determine the effect of increments in $\Delta T$ on the maximum value of $\tau$ (Meza and Varas, 2000).

3.3.2. Hargreaves model. Hargreaves and Samani (1982) proposed an empirical equation that took the form of a linear regression model between the relative incoming solar radiation and the square root of $\Delta T$ :

$$
\frac{H}{H_{\mathrm{o}}}=a_{\mathrm{H}}+b_{\mathrm{H}} \Delta T^{0.5}
$$

3.3.3. Garcia model. The model described by Garcia (1994) is the only attempt made to estimate incoming solar radiation in Peru. The model is an adaptation of the Ångström-Prescott model:

$$
\frac{H}{H_{\mathrm{o}}}=a_{\mathrm{G}}+b_{\mathrm{G}} \frac{\Delta T}{N}
$$

Using monthly estimates, Garcia (1994) proposed the following values:

- $a=0.060$ and $b=0.640$ for the central coast;

- $a=0.360$ and $b=0.211$ for the northern coast; 
- $a=0.457$ and $b=0.207$ for the central highlands;

- $a=0.230$ and $b=0.380$ for the southern highlands.

\subsection{Calibration and validation}

To calibrate and validate the Ångström-Prescott model, historical records from each weather station were used for those periods in which parallel information on incoming solar radiation and sunshine hours were available. The values of $H_{\mathrm{o}}$ and $N$ were calculated according to the day of the year and the latitude of each locality (Peixoto and Oort, 1992). The database was split into two parts. The first subset, $66 \%$ of the total data, was used to calibrate the model, using a linear regression analysis to find the empirical coefficients ( $a$ and $b$ ) of the Ångström-Prescott model. The remaining data were used to validate the model. The adequacy of the model was assessed by calculating the Pearson product moment correlation coefficient $r$, relative error and mean-square error (MSE). Analyses of residuals, as well as normal plots, were used to identify possible inadequacies in the models or problems in the data.

To estimate incoming solar radiation using temperatures recorded on a daily basis, the models proposed by Garcia (1994), Hargreaves and Samani (1982), and Bristow and Campbell (1984) were tested in order to evaluate which was the best to apply to the study area. As in the previous case, all the available information for each location was split into two sets. It should be noted that the empirical coefficient $a_{\mathrm{B}}$ used in the Bristow-Campbell model was calculated as the sum of the empirical coefficients $a$ and $b$ found for the Ångström-Prescott model, since they share the same physical explanation. The statistical analyses performed to validate the model were similar to those described for the Ångström-Prescott model.

\section{RESULTS AND DISCUSSION}

\subsection{Factors affecting the spatial distribution of $\tau$}

Figure 2 shows an overview of climatic variability in Peru, using monthly values of maximum and minimum temperatures and precipitation for the coast, the mountains and the jungle. However, within these zones, major variations occur that or caused by other climatic factors.

Figure 3 shows lines connecting points with the same values of atmospheric transmissivity; these lines represent the variation in time and space of this variable. The lines corresponding to the minimum and maximum values of atmospheric transmissivity, i.e. $30 \%$ and $80 \%$ respectively, occur on the central and southern arid coastal zones, respectively. However, monthly climate values, recorded at weather stations,
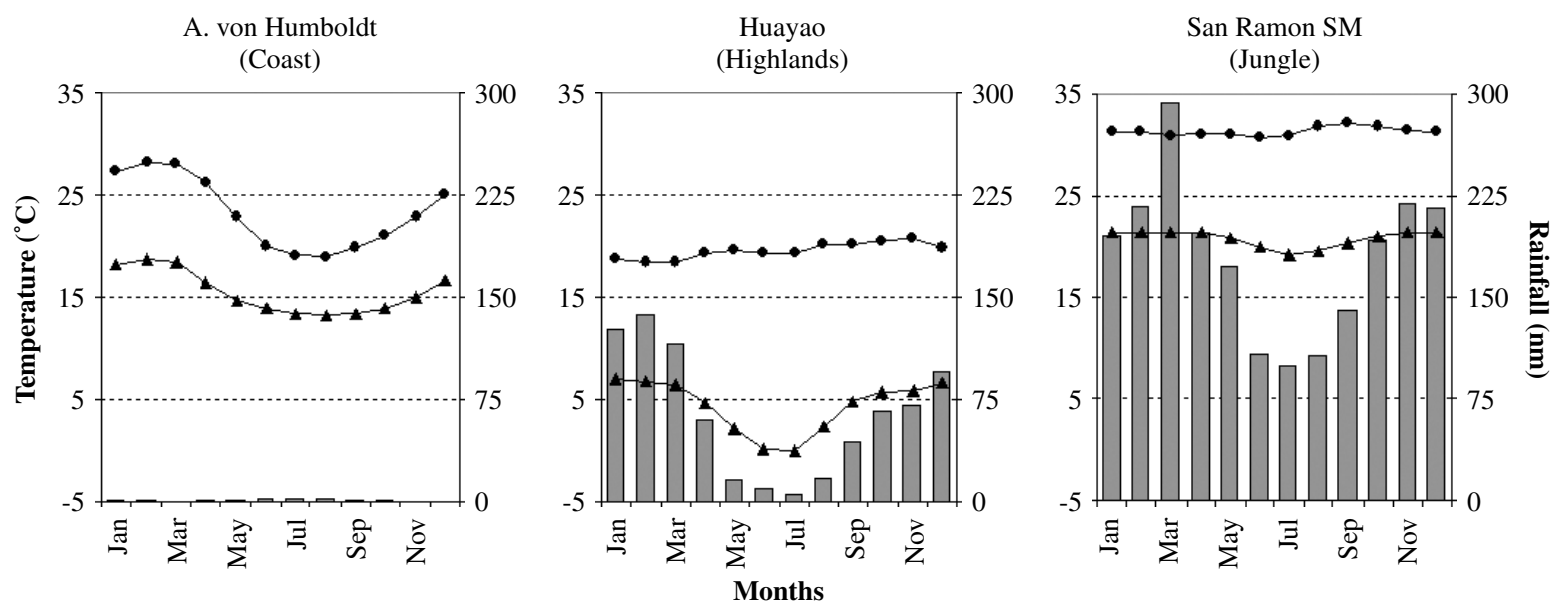

Figure 2. Climatic differences in maximum temperature (•), minimum temperature $(\boldsymbol{\Delta})$ and rainfall $(\square)$ for three weather stations representative of the coast, the highlands and the jungle of Peru 

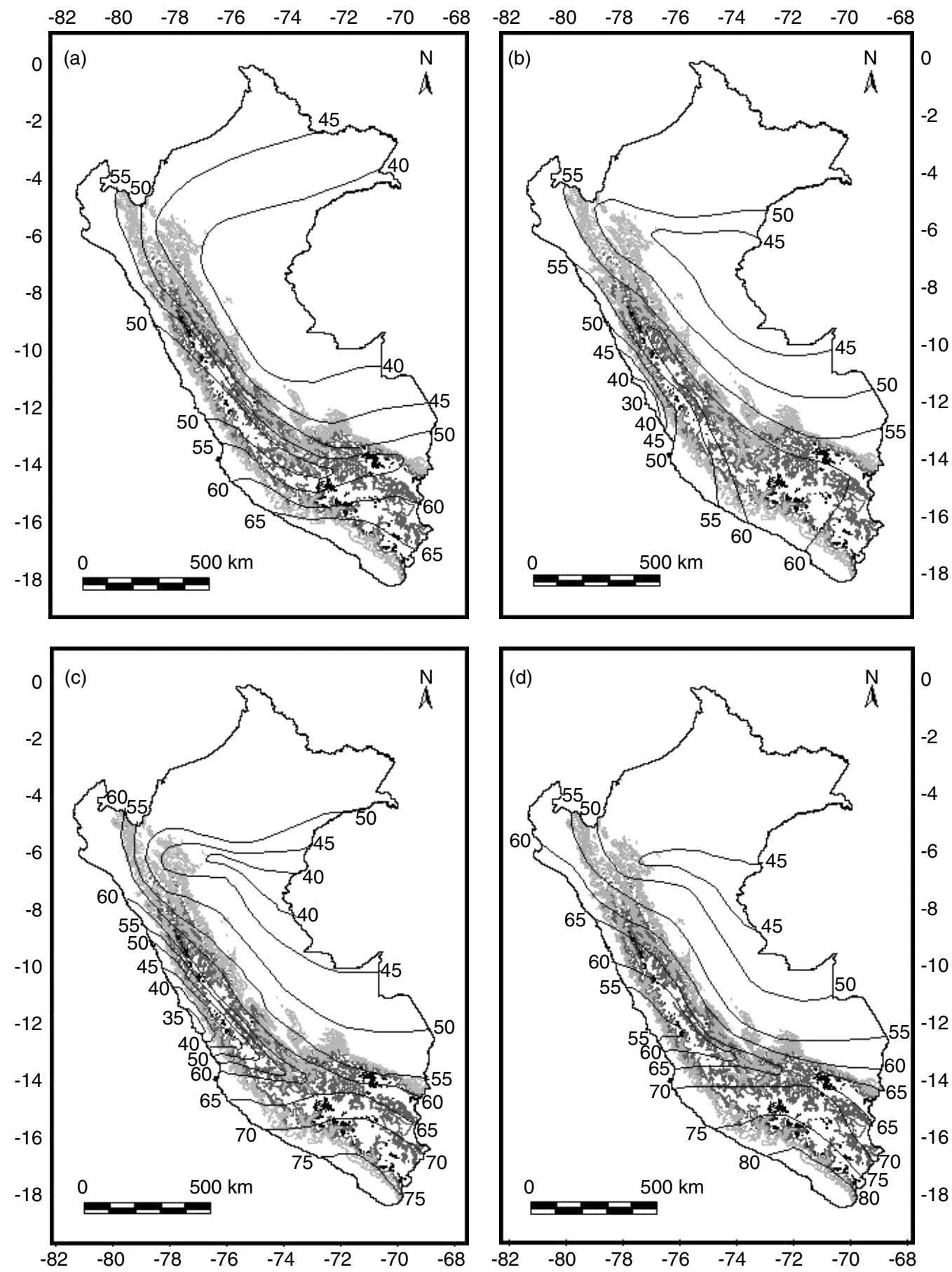

Figure 3. Climate maps of atmospheric transmissivity (\%) in different seasons in Peru: (a) March, (b) June, (c) September and (d) December. Latitude and longitude $\left(^{\circ}\right)$ are shown at the top (or bottom) and side respectively of each map

reached 29\% in August at Alexander von Humboldt and 85\% in November at La Joya. The highest coefficient of variation was reached on the central arid coastal zone (17\%), and the lowest value (4\%) occurred on the northern arid coastal zone. 
The South Pacific high anticyclone, the Andes mountain range and the Humboldt Current (cool water) affect the arid coastal zone. The effect of the latter decreases to the north of latitude $10^{\circ} \mathrm{S}$, where it interacts with the warm water current of El Niño.

The subsidence layer caused by the South Pacific high results in the development of a strong temperature inversion over the coastal waters and the coastline. This layer may extend up to $110 \mathrm{~km}$ offshore (normally from 10 to $30 \mathrm{~km}$ ), reaching heights of $1800 \mathrm{~m}$ a.s.l. and trapping stratus cloud, fog, mist, and light drizzle beneath it (Gilford et al., 1992). In July, the South Pacific high reaches its northernmost position, and the lowest sea-surface temperature occurs along the Pacific arid coastal zone. The conjunction of these two phenomena forms a very strong inversion layer, reducing $\tau$ throughout the area due to the presence of clouds. However, the low-level jet stream, termed 'Paracas' (usually found below $600 \mathrm{~m}$ a.s.l., parallel to the coastline, between the latitudes of $13^{\circ} \mathrm{S}$ and $19^{\circ} \mathrm{S}$ ), in combination with a sea breeze causes strong local winds that alter the moisture profile. This clears the atmosphere, thus increasing $\tau$ in the southern coastal arid zone despite its low altitude.

In the northern arid coastal zone, the effect of the subsidence is lost as a result of the warm water current of El Niño and the large distance to the South Pacific high, which moves southwards from December to February. However, during these summer months, the southward movement of the near-equatorial trough (NET) in the north of Peru does not lead to an increase in $\tau$ on the northern arid coastal zone despite the mountainous terrain in northern South America, which breaks up the NET (Gilford et al., 1992).

Figure 3(a) to (d) are characterized by a gradient of $\tau$ parallel to the Andes, as a result of altitude and topographic barrier effects over clouds and aerosols in the atmosphere. At the higher altitudes in the mountains the atmospheric thickness is decreased, in turn decreasing the filter effects that govern incoming solar radiation. The mountains are also the major topographic barriers to weather systems and airflow below $2500 \mathrm{~m}$ a.s.l., thus preventing the regular exchange of air between the Pacific and Atlantic air masses. This leads to a difference in the atmospheric moisture content on both sides of the Andes, which is eventually expressed in the values of $\tau$.

Precipitation over the Andean High Plateau exhibits a pronounced annual cycle, with more than $70 \%$ of the rain being concentrated in the 2 to 3 month wet season that occurs during the austral summer (Aceituno and Montecinos, 1993). This wet-season precipitation is also associated with the development of convective clouds over the central Andes and the southwestern part of the Amazon basin (Horel et al., 1989). Within this rainy season, the Andean High Plateau experiences both rainy and dry periods, which range between 5 and 10 days in duration (Aceituno and Montecinos, 1993). About 50\% of the area is covered by cold clouds during the afternoons during these rainy episodes, whereas convective clouds are almost non-existent during the dry episodes (Garreaud, 1999). These observations explain both the occurrence of $\tau$ values lower than $65 \%$ during the winter and the occurrence of rainfall during the summer, despite the fact that in some areas the altitude is more than $4000 \mathrm{~m}$ a.s.l. However, $\tau$ values that are higher than $75 \%$ can be reached during spring, due to the sun being positioned over the Southern Hemisphere and the cloud systems not yet being formed. The intense heating of the Andean High Plateau that occurs in the summer, as a result of solar radiation, forms the warm-cored, thermal anticyclone known as the Bolivian high. This is responsible for lifting and spreading moist, unstable, low-level Amazonian air over the central Andes, so governing $\tau$.

The distribution of $\tau$, over space and time, in the jungle zone corresponds to the cloud cover maps presented by Gilford et al. (1992). Characteristics of the dry season are a decrease in afternoon cloud cover and an increased number of clear days. This results in $\tau$ being higher during the dry season than it is during the wet season.

\subsection{Model based on sunshine hours}

The results obtained from the process of validating the model based on sunshine hours, and the empirical coefficients for each weather station, are presented in Table III. Figure 4(a), (c), and (e) show observed versus estimated values from three representatives weather stations.

The empirical coefficients show high variation in terms of spatial distribution; this was also true for the values that occurred in the regions corresponding to the regions defined in the Garcia (1994) study. 
Table III. Values of the coefficients $a, b$ and $r$ for the Angström-Prescott model, the total number of days of data $n$ used in the estimation process, and the relative error and MSE found during the validation process

\begin{tabular}{|c|c|c|c|c|c|c|}
\hline Location & $a$ & $b$ & $r$ & $n$ & Error $(\%)$ & $\mathrm{MSE} \times 10^{-4}$ \\
\hline \multicolumn{7}{|l|}{ Coast } \\
\hline Miraflores & 0.355 & 0.392 & 0.895 & 2454 & -2.4 & 25 \\
\hline A. von Humboldt & 0.211 & 0.467 & 0.892 & 8124 & 12.9 & 47 \\
\hline San Camilo & 0.321 & 0.468 & 0.766 & 1494 & -0.4 & 57 \\
\hline La Joya & 0.593 & 0.181 & 0.781 & 7534 & 2.8 & 127 \\
\hline \multicolumn{7}{|l|}{ Highlands } \\
\hline Bambamarca & 0.322 & 0.336 & 0.803 & 1798 & 6.6 & 37 \\
\hline Weberbauer & 0.231 & 0.521 & 0.883 & 1239 & -2.7 & 40 \\
\hline Cosmos & 0.320 & 0.384 & 0.826 & 619 & 7.4 & 39 \\
\hline Huayao & 0.397 & 0.379 & 0.810 & 4190 & 2.2 & 51 \\
\hline Granja Kcayra & 0.376 & 0.364 & 0.768 & 1466 & 3.4 & 65 \\
\hline Chuquibambilla & 0.395 & 0.384 & 0.750 & 1261 & -2.1 & 102 \\
\hline Puno & 0.378 & 0.438 & 0.775 & 1870 & 9.2 & 72 \\
\hline Characato & 0.367 & 0.396 & 0.656 & 813 & 10.7 & 94 \\
\hline \multicolumn{7}{|l|}{ Jungle } \\
\hline San Ramon SM & 0.301 & 0.377 & 0.803 & 1828 & 6.6 & 48 \\
\hline El Porvenir & 0.278 & 0.320 & 0.792 & 1075 & 7.0 & 36 \\
\hline Bellavista & 0.355 & 0.341 & 0.784 & 476 & 5.9 & 44 \\
\hline
\end{tabular}

The relationships that exist between the relative sunshine hours and the empirical coefficients are not straightforward; this agrees with the findings of Frère et al. (1975). Therefore, it is very difficult to justify the use of a single set of empirical coefficients with regard to a vast region (country). This is especially true where there is a high diversity of ecological environments, as there is in Peru. A literature review undertaken by Martínez-Lozano et al. (1984) addresses the use of relationships between the two empirical coefficients and a number of individual variables (latitude, altitude, albedo, mean solar altitude, natural or artificial pollution and water vapour concentration). Glover and McCulloch (1958) related the coefficient $a$ to latitude $\phi$, proposing the expression $a=0.01+0.27 \cos \phi$. Neuwirth (1980) proposed an equation relating both empirical coefficients to altitude using 19 weather stations in Austria. However, after many analyses, we concluded that the empirical coefficients found in Peru are related to neither latitude nor altitude. Climatic factors, mountain chains and sea currents are the factors that determine the spatial distribution of incoming solar radiation.

\subsection{Models based on temperatures}

Figure 5 shows an example of the relationship that exists between the daily relative incoming solar radiation and the difference between maximum and minimum temperatures for three weather stations: one on the coast, one in the highlands and one in the jungle of Peru. The trends shown in these graphs suggest that a meaningful relationship may exist between these two variables for different areas of the country.

The values of the empirical coefficients found when calibrating the three evaluated models are presented in Table IV. Table V shows the correlation coefficient $r$ for the relationship between the observed and estimated incoming solar radiation values obtained in the validation, and Figure 4(b), (d), and (e) show this relationship for three representatives weather stations.

The Bristow-Campbell model showed the best fit for most of the localities in Peru (Table V). The Hargreaves model gave similar correlation values. However, despite these high correlations, in areas where minimum temperatures are negative and values of $\Delta T$ are low, the results obtained by using this model are strongly biased. This can be seen in the relative error and MSE of the locality of Cosmos in Table V. In addition, the parameters determined by the Bristow-Campbell model have a better physical explanation. 


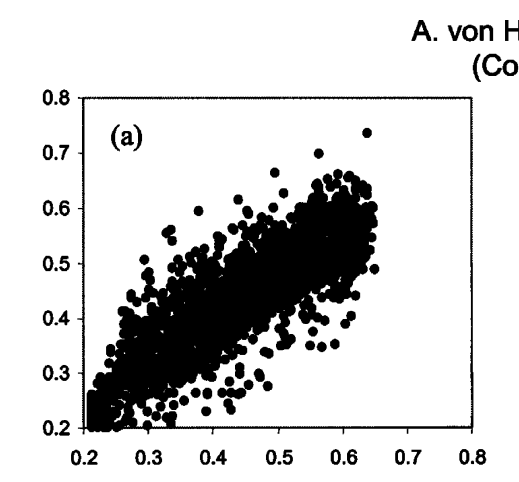

von Humboldt

(Coast)
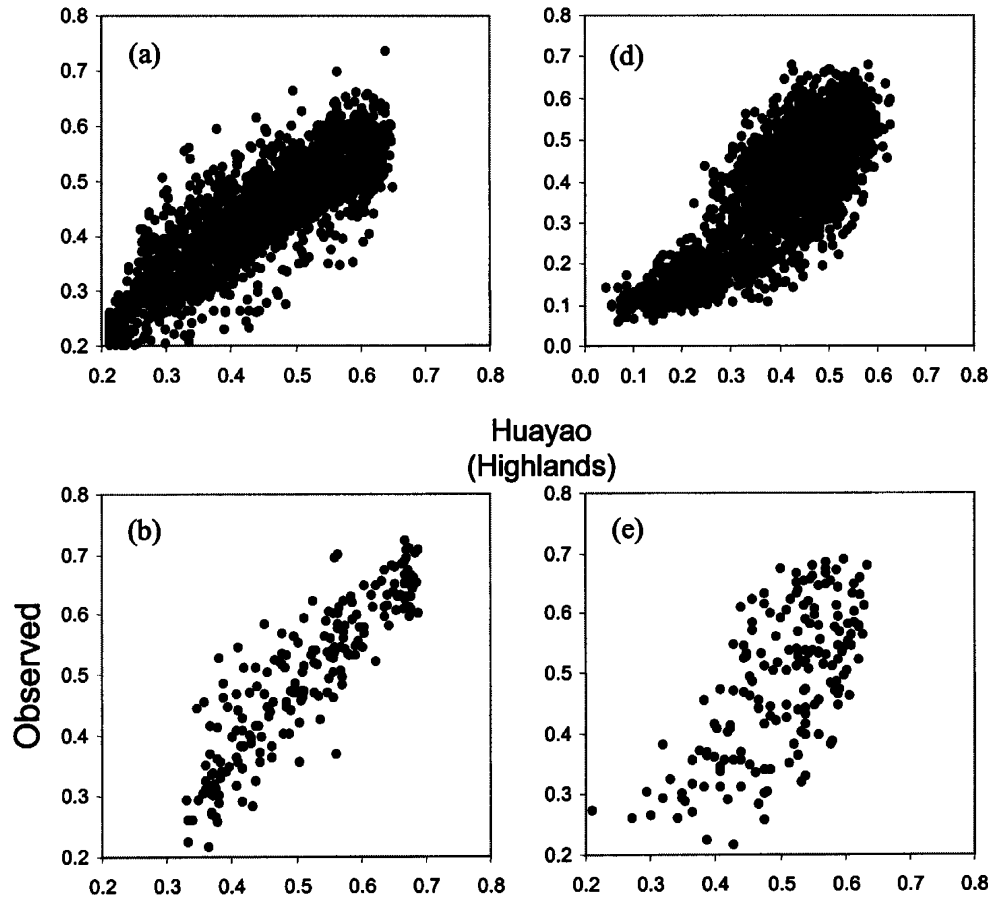

Huayao

(Highlands)

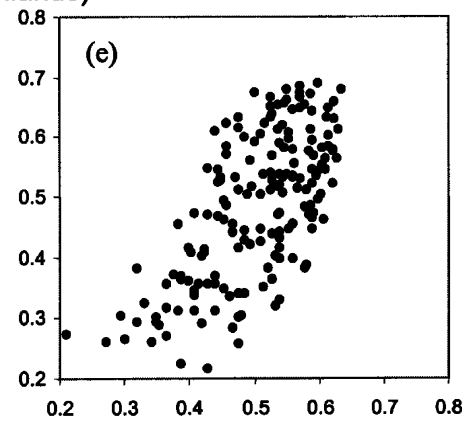

San Ramon SM

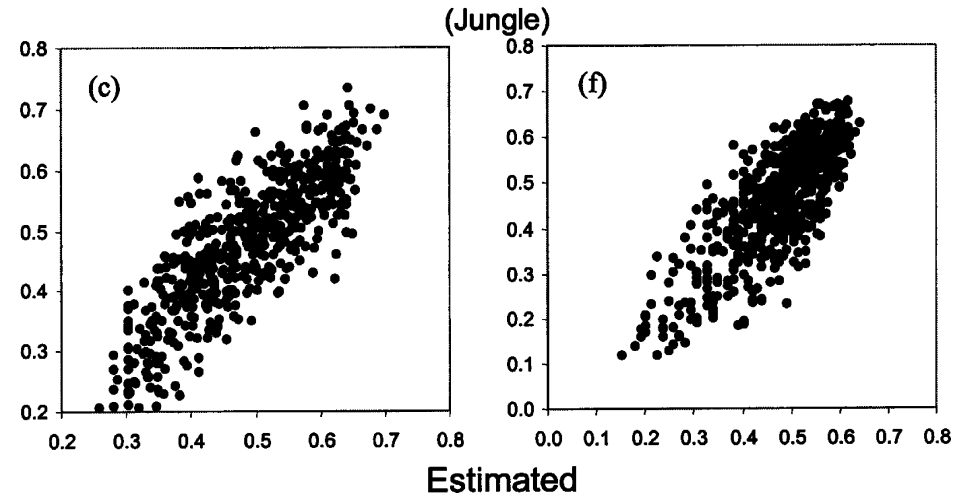

Figure 4. Observed versus estimated data at the time of validation from three weather stations representative of the coast, the highlands, and the jungle of Peru. (a), (c), and (e) correspond to the validation of the Ångström-Prescott model, and (b), (d), and (f) correspond to the validation of the Bristow-Campbell model

With regard to data from weather stations in the highlands, coast and jungle, the worst cases found during the analysis of residuals are shown in Figure 6. In most of the cases, the residuals were randomly distributed around zero, with more than $95 \%$ of the data points falling within the interval defined by $e= \pm 2 s$, thus indicating the acceptability of the model used.

The normal plot (Figure 7) shows an s-shaped curve, indicating the possibility of skewness in the distribution. The data from the jungle seem to be the most affected by a possible departure from normality.

Since the absolute values of the maximum and minimum temperatures, and the differences between them, are greatly influenced by topography, latitude and altitude, among other factors, the coefficients $b_{\mathrm{B}}$ and $c_{\mathrm{B}}$ proposed should be applied only in areas where similar thermal regimes prevail. Therefore, in order to increase 

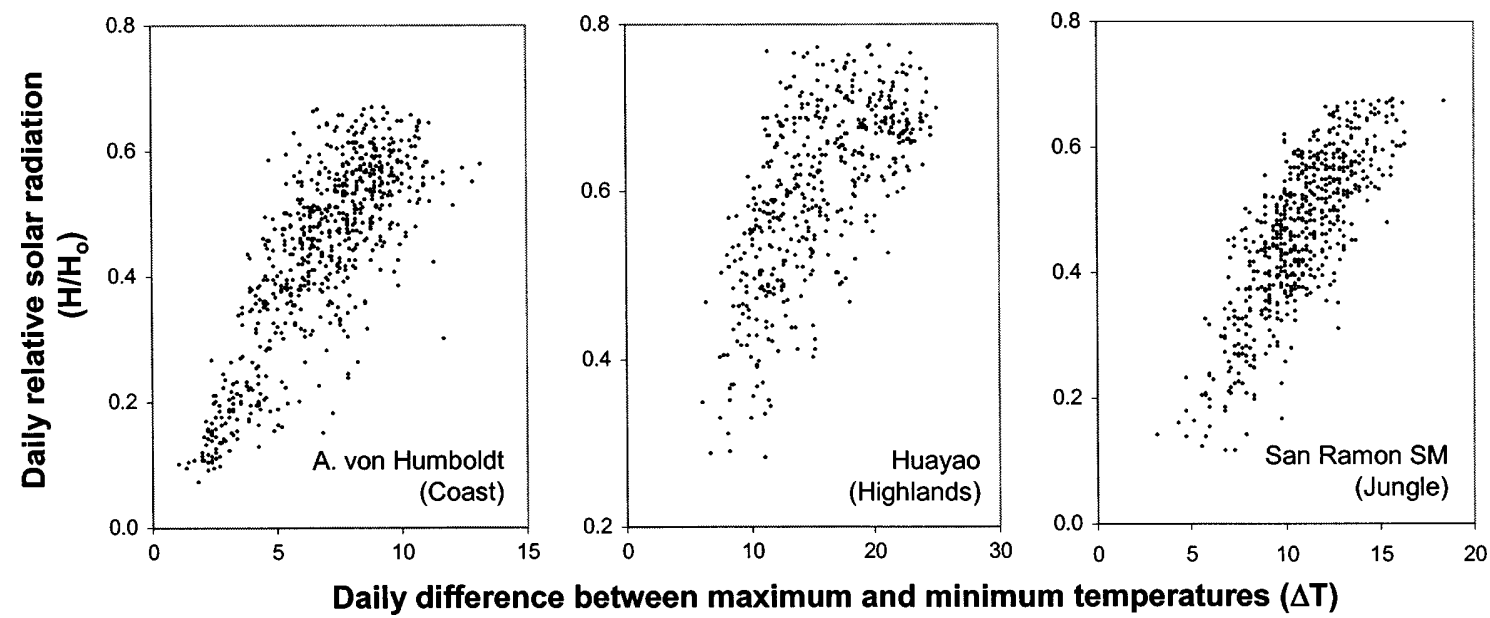

Figure 5. Relationship between daily relative solar radiation $H / H_{\mathrm{o}}$ and daily difference between maximum and minimum temperatures $\Delta T$ for three weather stations representative of the coast, the highlands and the jungle of Peru

Table IV. Values of the empirical coefficients found in the calibration process and the total number of days of data used for each location

\begin{tabular}{|c|c|c|c|c|c|c|c|c|}
\hline \multirow[t]{2}{*}{ Location } & \multicolumn{2}{|c|}{ Garcia } & \multicolumn{2}{|c|}{ Hargreaves } & \multicolumn{3}{|c|}{ Bristow-Campbell } & \multirow[t]{2}{*}{$n$ (days) } \\
\hline & $a_{\mathrm{G}}$ & $b_{\mathrm{G}}\left(\mathrm{h}^{\circ} \mathrm{C}^{-1}\right)$ & $a_{\mathrm{H}}$ & $b_{\mathrm{H}}\left({ }^{\circ} \mathrm{C}^{-0.5}\right)$ & $a_{\mathrm{B}}$ & $b_{\mathrm{B}}\left({ }^{\circ} \mathrm{C}^{-1}\right)$ & $c_{\mathrm{B}}$ & \\
\hline \multicolumn{9}{|l|}{ Coast } \\
\hline Miraflores & 0.200 & 0.395 & -0.167 & 0.221 & 0.75 & 0.04 & 1.49 & 2398 \\
\hline A. von Humboldt & 0.074 & 0.571 & -0.235 & 0.246 & 0.68 & 0.06 & 1.42 & 9141 \\
\hline San Camilo & 0.463 & 0.120 & 0.075 & 0.138 & 0.79 & 0.09 & 1.05 & 1496 \\
\hline \multicolumn{9}{|l|}{ Highlands } \\
\hline Bambamarca & 0.294 & 0.233 & 0.117 & 0.118 & 0.66 & 0.23 & 0.80 & 1355 \\
\hline Weberbauer & 0.187 & 0.259 & -0.160 & 0.173 & 0.75 & 0.04 & 1.28 & 1071 \\
\hline Cosmos & 0.088 & 0.486 & -0.299 & 0.250 & 0.70 & 0.03 & 1.62 & 515 \\
\hline Huayao & 0.390 & 0.170 & 0.121 & 0.123 & 0.78 & 0.11 & 0.97 & 3591 \\
\hline Granja Kcayra & 0.363 & 0.137 & 0.102 & 0.110 & 0.74 & 0.11 & 0.92 & 1307 \\
\hline Chuquibambilla & 0.471 & 0.106 & 0.239 & 0.089 & 0.78 & 0.19 & 0.76 & 984 \\
\hline Puno & 0.467 & 0.178 & 0.192 & 0.133 & 0.82 & 0.20 & 0.87 & 1437 \\
\hline Characato & 0.252 & 0.044 & 0.166 & 0.121 & 0.76 & 0.16 & 0.91 & 2089 \\
\hline \multicolumn{9}{|l|}{ Jungle } \\
\hline San Ramon SM & 0.045 & 0.466 & -0.364 & 0.253 & 0.68 & 0.02 & 1.86 & 1909 \\
\hline El Porvenir & 0.174 & 0.223 & -0.110 & 0.148 & 0.60 & 0.06 & 1.21 & 1564 \\
\hline Bellavista & 0.195 & 0.302 & -0.105 & 0.175 & 0.70 & 0.06 & 1.22 & 692 \\
\hline
\end{tabular}

the applicability of this work, empirical relationships were found which could be used to determine values of $b_{\mathrm{B}}$ and $c_{\mathrm{B}}$ as a function of $\Delta T$ and latitude.

Figure 8(a) shows the relationship between the coefficients $b_{\mathrm{B}}$ and $c_{\mathrm{B}}$ derived from the Bristow-Campbell model, and Figure 8(b) and (c) shows the relationship between the values presented in Table IV and those estimated using Equations (6) and (7):

$$
\begin{aligned}
& c_{\mathrm{B}}=2.116-0.072 \Delta T+57.574 \exp (\phi) \\
& b_{\mathrm{B}}=0.107 c_{\mathrm{B}}^{-2.6485}
\end{aligned}
$$


Table V. Comparison of three models, in terms of correlation coefficient, relative error and MSE, between observed and estimated incoming solar radiation at the time of validation; $n$ is the number of days of data used

\begin{tabular}{|c|c|c|c|c|c|c|c|c|c|c|}
\hline \multirow[t]{2}{*}{ Location } & \multicolumn{3}{|c|}{ Garcia } & \multicolumn{3}{|c|}{ Hargreaves } & \multicolumn{3}{|c|}{ Bristow-Campbell } & \multirow[t]{2}{*}{$n$ (days) } \\
\hline & $r$ & $\begin{array}{c}\text { Error } \\
(\%)\end{array}$ & $\operatorname{MSE} \times 10^{-4}$ & $r$ & $\begin{array}{c}\text { Error } \\
(\%)\end{array}$ & MSE $\times 10^{-4}$ & $r$ & $\begin{array}{c}\text { Error } \\
(\%)\end{array}$ & $\mathrm{MSE} \times 10^{-4}$ & \\
\hline \multicolumn{11}{|l|}{ Coast } \\
\hline Miraflores & 0.716 & 3.3 & 48 & 0.733 & 3.1 & 45 & 0.741 & 3.8 & 43 & 816 \\
\hline A. von Humboldt & 0.752 & 18.0 & 89 & 0.800 & 15.7 & 74 & 0.816 & 14.1 & 70 & 3108 \\
\hline San Camilo & 0.280 & 3.2 & 90 & 0.471 & 1.9 & 76 & 0.445 & 3.9 & 74 & 509 \\
\hline \multicolumn{11}{|l|}{ Highlands } \\
\hline Bambamarca & 0.629 & 10.9 & 70 & 0.646 & 11.2 & 69 & 0.647 & 12.6 & 73 & 461 \\
\hline Weberbauer & 0.621 & 4.5 & 84 & 0.676 & 2.2 & 81 & 0.666 & 3.2 & 82 & 365 \\
\hline Cosmos & 0.716 & 9.7 & 81 & 0.732 & 452.0 & 40905 & 0.714 & 8.5 & 85 & 176 \\
\hline Huayao & 0.592 & 5.3 & 76 & 0.664 & 3.2 & 65 & 0.649 & 4.6 & 64 & 1221 \\
\hline Granja Kcayra & 0.525 & 12.4 & 98 & 0.585 & 10.4 & 83 & 0.587 & 11.6 & 84 & 445 \\
\hline Chuquibambilla & 0.480 & 7.4 & 100 & 0.567 & 3.1 & 86 & 0.606 & 3.6 & 81 & 339 \\
\hline Puno & 0.441 & 8.3 & 104 & 0.516 & 5.5 & 90 & 0.500 & 7.2 & 92 & 795 \\
\hline Characato & 0.062 & -47.4 & 972 & 0.245 & 5.4 & 80 & 0.379 & 7.5 & 81 & 711 \\
\hline \multicolumn{11}{|l|}{ Jungle } \\
\hline San Ramon SM & 0.792 & 7.5 & 55 & 0.799 & 7.2 & 54 & 0.802 & 7.5 & 54 & 650 \\
\hline El Porvenir & 0.685 & 5.0 & 43 & 0.695 & 4.6 & 42 & 0.709 & 4.1 & 41 & 532 \\
\hline Bellavista & 0.772 & 2.3 & 47 & 0.794 & 2.3 & 41 & 0.789 & 2.3 & 41 & 461 \\
\hline
\end{tabular}

The validation analyses showed high residual values at Puno. This weather station is on the boundaries of Titicaca Lake, which covers an area of $8300 \mathrm{~km}^{2}$ and has a regulatory effect on the temperature of the surrounding area, preventing the occurrence of the extremely low minimum temperatures characteristic of high altitudes. This leads to a decrease in $\Delta T$, giving non-representative values when used to produce a generic equation. Therefore, this set of coefficients was eliminated when determining the parameters for Equation (6).

It should be noted that pyranometers are more accurate than actinographs when measuring incoming solar radiation. This could have affected the values of the empirical coefficients obtained for San Ramon SM, El Porvenir, Bambamarca, Bellavista and La Joya. However, there are no pyranometers at these places. Therefore, use of the information provided by actinographs constitutes the best approach available.

Applications of the present work are strongly related to areas around the central Andes; however, because most of the new techniques based on radiative fluxes and/or satellite have still not been calibrated and validated for use in complex terrains like mountains, the empirical alternatives can be applied to other mountain chains around the world, using previously calibrated coefficients.

\section{CONCLUSIONS}

Many factors other than altitude affect, directly and/or indirectly, atmospheric transmissivity in complex terrains. The South Pacific high, the NET, the Bolivian high, low-level jets, the Andes mountain range and the Humboldt and El Niño currents, both separately and when interacting, can modify the distribution of solar radiation in space and time. The interactions of all the above produce the widely differing scenarios of incident solar radiation observed.

Using the Ångström-Prescott model, the spatial variation obtained for the values of empirical coefficients throughout the different regions of the country casts doubt upon the validity of applying only a single 

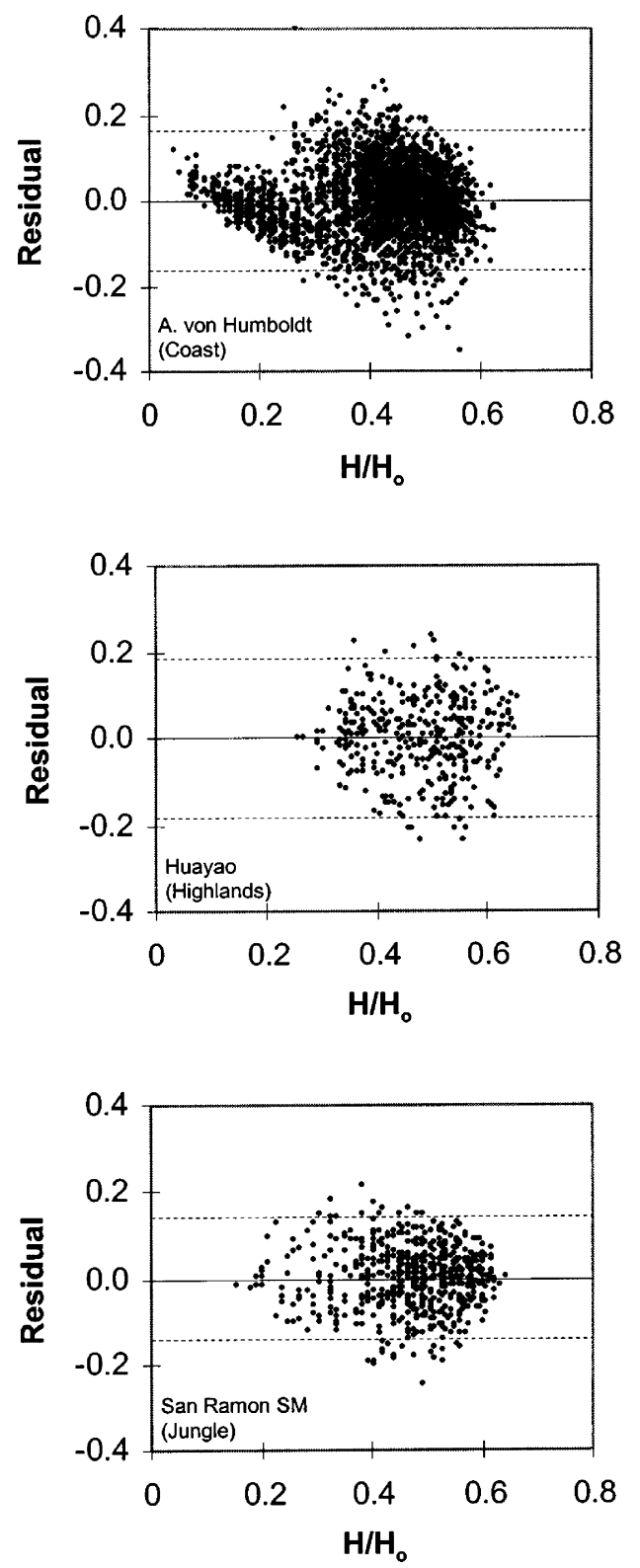

Figure 6. Residual plots from three weather stations representative of the coast, the highlands and the jungle of Peru, at the time of validation of the Bristow-Campbell model

set. Owing to the higher correlation coefficients and the lower relative errors and MSEs obtained for the relationship between relative incoming solar radiation and relative sunshine hours, the empirical coefficients of the Ångström-Prescott model are recommended for use in the regions they represent.

Among the models tested and used to estimate incoming solar radiation as a function of temperature, the Bristow-Campbell model is recommended as that most applicable to Peru.

The empirical relationships used to estimate incoming solar radiation based on relative sunshine hours demonstrated more accuracy than those based on temperature. Values of the empirical coefficients given here are on an annual basis. Their utilization for estimating incident solar radiation must be done only on an annual basis. 

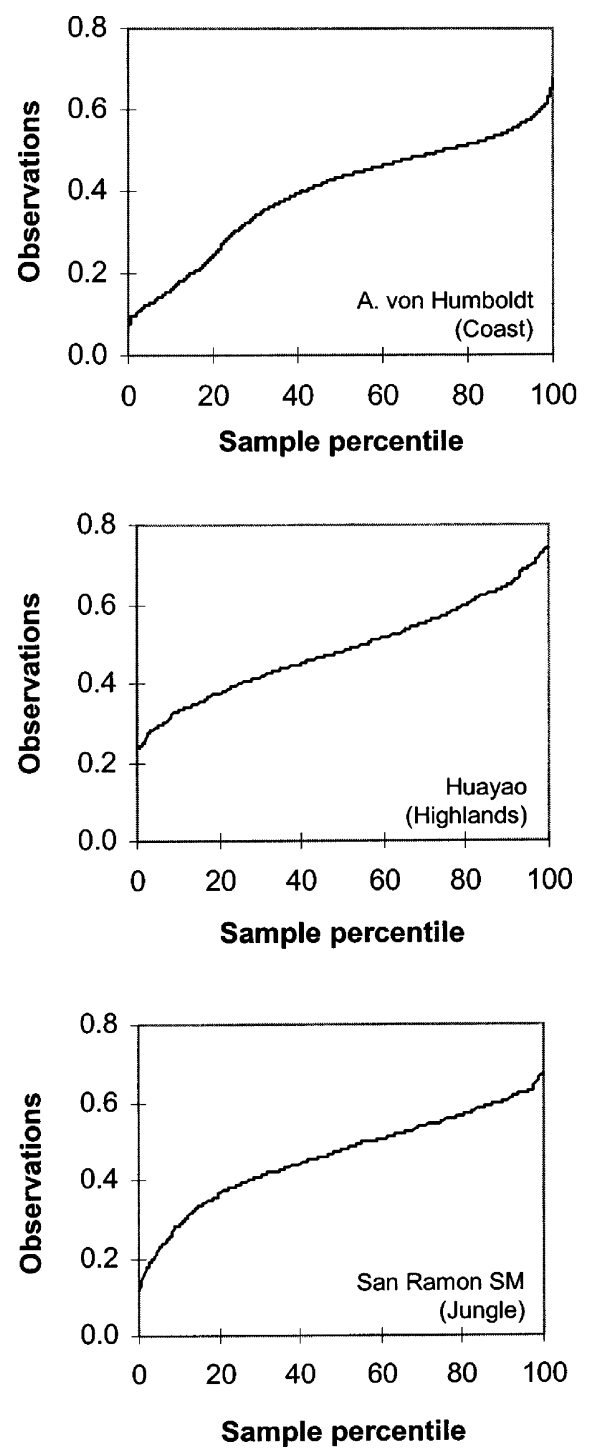

Figure 7. Normal probability plots from three weather stations representative of the coast, the highlands and the jungle of Peru, at the time of validation of the Bristow-Campbell model

\section{ACKNOWLEDGEMENTS}

We would like to thank the Global Environment Facility (GEF) for funding this project (PER/98/G31 'Photovoltaic-based rural electrification in Peru') and the Ministry of Energy and Mines of Peru (DEP-MEM) for the support it gave to the project. Special thanks are given to Eng. Emilio Mayorga.

Thanks are also due to the directors of SENAMHI for the facilities they extended to us in the development of the present work, and to the project's workgroup, the members of which contributed to the quality control process applied to the data. We would also like to thank Dr Jetse Stoorvogel for the contributions made to the present paper, and the United States Agency for International Development (USAID), through its Soil Management Collaborative Research Program (SM-CRSP) financing the project 'Tradeoffs in Sustainable Agriculture and the Environment in the Andes: A Decision Support System for Policy Makers'. Last, but not least, the Consultative Group on International Agricultural Research-Libraries and Information Services Consortium (CGIAR-LIS) are thanked. 

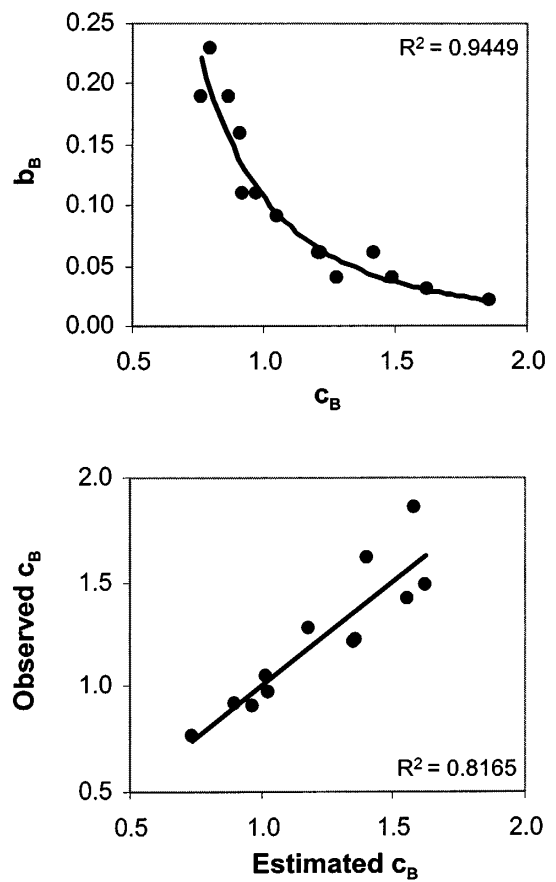

(b)

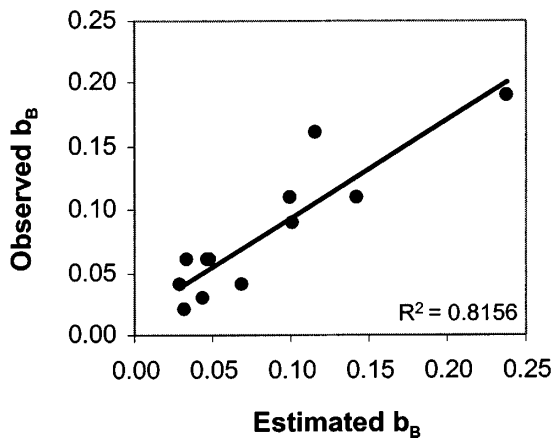

(c)

Figure 8. Relationship between $c_{\mathrm{B}}$ and $b_{\mathrm{B}}$, the empirical coefficients of the Bristow-Campbell model (a), and plots of observed versus estimated values for each of the coefficients: $c_{\mathrm{B}}$ (b) and $b_{\mathrm{B}}(\mathrm{c})$

\section{REFERENCES}

Aceituno P, Montecinos A. 1993. Circulation anomalies associated with dry and wet periods in the South American Altiplano. In Proceedings of Fourth International Conference on Southern Hemisphere Meteorology, Hobart, Australia. American Meteorological Society: 330-331.

Ångström A. 1924. Solar and terrestrial radiation. Quarterly Journal of the loyal Meteorological Society 50: $121-125$.

Atwater MA, Ball JT. 1978. A numerical solar radiation model based on standard meteorological observations. Solar Energy 21: $163-170$.

Bastos EJB, Funatsu BM, Bonfim A, Moraes EC, Ceballos JC. 1996. Estimativa da radiação solar global para a américa do sul via satellite. In Proceedings IX Congresso Brasileiro de Meteorologia, Campos do Jordão, Sao Pablo, Brasil; 596-600 (in Portuguese, with English abstract).

Bristow K, Campbell G. 1984. On the relationship between incoming solar radiation and daily maximum and minimum temperature. Agricultural and Forest Meteorology 31: 159-166.

Ceballos JC, Moura GBA. 1997. Solar radiation assessment using Meteosat 4-VIS imagery. Solar Energy 60: $209-219$.

Cengiz HS, Gregory JM, Seabaugh JL. 1981. Solar radiation prediction from other climate variables. Transactions of the ASAE 24: 1269-1272.

Dissing D, Wendler G. 1998. Solar radiation climatology of Alaska. Theoretical and Applied Climatology 61: $161-175$.

Frère M, Rijks J, Rea J. 1975. Estudio Agroclimatológico de la Zona Andina (Informe Técnico). Proyecto Interinstitucional FAO/UNESCO/WMO, Rome, Italy. 
Garatuza-Payan J, Pinker RT, Shuttleworth WJ, Watts CJ. 2001. Solar radiation and evapotranspiration in northern Mexico estimated from remotely sensed measurements of cloudiness. Hydrological Sciences Journal 46(3): 465-478.

Garcia JV. 1994. Principios Físicos de la Climatología. Ediciones UNALM, Universidad Nacional Agraria La Molina: Lima, Peru. Garreaud RD. 1999. Multiscale analysis of the summertime precipitation over the central Andes. Monthly Weather Review 127: $901-921$

Gilford MT, Vojtesak MJ, Myles G, Bonam RC, Martens DL. 1992. South America — south of the Amazon River: a climatological study. USAF Environmental Technical Applications Center (USAFETAC/TN-92/004), Scott Air Force Base, Illinois, USA.

Glover J, McCulloch JSF. 1958. The empirical relation between solar radiation and hours of sunshine. Quarterly Journal of the Royal Meteorological Society 84: 172-175.

Goodin DG, Hutchinson JMS, Vanderlip RL, Knapp MC. 1999. Estimating solar irradiance for crop modeling using daily air temperature data. Agronomy Journal 91: 845-851.

Gultepe I, Isaac GA, Strawbridge KB. 2001. Variability of cloud microphysical and optical parameters obtained from aircraft and satellite remote sensing measurements during RACE. International Journal of Climatology 21: 507-525.

Hargreaves G, Samani Z. 1982. Estimating potential evapotranspiration. Journal of Irrigation and Drainage Engineering, ASCE 108: $225-230$.

Horel J, Nahmann A, Geisler J. 1989. An investigation of the annual cycle of the convective activity over the tropical Americas. Journal of Climate 2: 1388-1403.

Martínez-Lozano JA, Tena F, Onrubia JE, De la Rubia J. 1984. The historical evolution of the Ångström formula and its modification: review and bibliography. Agricultural and Forest Meteorology 33: 109-128.

Mahmood R, Hubbard KG. 2002. Effect of time of temperature observation and estimation of daily solar radiation for the northern Great Plains, USA. Agronomy Journal 94: 723-733.

Meza F, Varas E. 2000. Estimation of mean monthly solar global radiation as a function of temperature. Agricultural and Forest Meteorology 100: 231-241.

Neuwirth F. 1980. The estimation of global and sky radiation in Austria. Solar Energy 24: 421-426.

Peixoto JP, Oort AH. 1992. Physics of Climate. American Institute of Physics: New York, USA.

Prescott JA. 1940. Evaporation from a water surface in relation to solar radiation. Transactions of the Royal Society of South Australia 64: $114-125$.

Tsuji GY, Hoogenboom G, Thornton PK. 1998. Understanding Options for Agricultural Production. Kluwer Academic Publishers: UK.

Weymouth G, Le Marshall J. 1994. An operational system to estimate insolation over the Australian region. In Proceedings of Pacific Ocean Remote Sensing Conference, Australia; 443-449. 